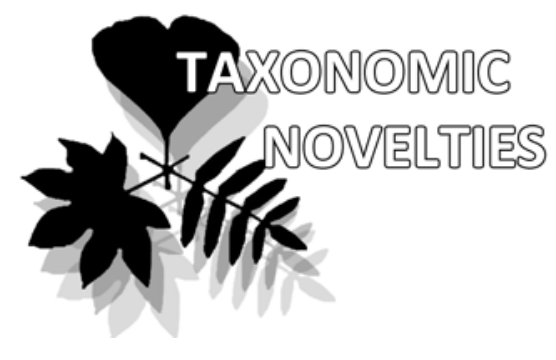

\title{
A note on Nardia japonica Steph. (Gymnomitriaceae)
}

\author{
Vadim A. Bakalin* \& Ksenia G. Klimova
}

Vadim A. Bakalin*

e-mail: vabakalin@gmail.com

Ksenia G. Klimova

e-mail: ksenia.g.klimova@mail.ru

Botanical Garden-Institute FEB RAS, Vladivostok, Russia

* corresponding author

Manuscript received: 29.09.2016

Review completed: 19.10.2016

Accepted for publication: 10.11.2016

Published online: 18.11.2016

\begin{abstract}
A B S T R A C T
An attempt to clarify the morphological concept of Nardia japonica is provided. This species is characterized by coarsely granulate oil bodies which contradicts to homogenous oil bodies ascribed to this species by several authors. The plants bearing homogenous oil bodies belong to the new, previously undescribed, Nardia pacifica Bakalin sp. nov. The report of $N$. lescurii from Japan seems to be based on misidentification of N. japonica, while the former is the Appalachian endemic species.
\end{abstract}

Ke y w o r d s : Hepaticae, Nardia, new taxa, taxonomy, oil bodies, ecology

\section{PE 3 Ю M E}

Бакалин В.А., КАимова К.Г. Заметка о Nardia japonica Steph. (Gymnomitriaceae). Уточнена морфологическая концепция Nardia japonica. Этот виА характеризуется грубо зернистыми масляными тельцами, что противоречит указаниям на гомогенные масляные тельца, приписываемые этому вилу ряАом авторов. Растения, имеющие гомогенные масляные тела, принадлежат к новому, ранее не описанному Nardia pacifica Bakalin sp. nov. Сообщение о $N$. lescurii из Японии очевидно основано на ошибочном определении $N$. japonica, в то время как $N$. lescurii явцяется эндемиком Аппалачей.

К $\mathbf{ю}$ ч е в ы е с м о в а : Hepaticae, Nardia, таксономия, масляные тельца, экология

\section{NTRODUCTION}

Nardia japonica Steph. was described from northern Hokkaido from the peninsula adjacent to Kunashir Island. Although Stephani's $(1897:$ 101) protologue citation is "Shirekoko, Tosa", the label of the holotype is "Montages in Shiretoko" (G11787/64213!, cf. Váňa 1976) that is in Hokkaido, but not from Kochi Prefecture in Shikoku (former Tosa). S. Hattori in his note on holotype label also indicated "proper species distributed in northern Japan”. Among Stephani’s species of Narida the taxon was prominent due to underleaves "utroque latere foliis accreta" (= "connate with both lateral leaves"). N. japonica was circumscribed and illustrated in Amakawa's (1959) treatment of Japanese Jungermanniaceae and shortly after was found in North-East Asia and as far as in North-East Europe (Schljakov 1981). Currently Nardia japonica is reported from Japan (Hokkaido, Honshu, cf. Yamada \& Iwatsuki 2006), NorthEast Asia (including Yakutiya in East Siberia), Russian Pacific, then westward in the areas under strong Atlantic influence in the North of European Russia (Konstnatinova et al. 2009) and as well as in Finland (Potemkin 2004). The reports of the species from the New World are from Alaska, British Columbia, Washington and Oregon from the land closely adjacent to the Pacific coast (Hong \& Váňa 2000). There were no formal problems in understanding of this species until Furuki (1997) reported in Japan an Appalachian endemic N. lescurii (Aust.) Underw. as closely related to $N$. japonica, but particularly diffe- rent in coarsely granulate oil bodies. After, Bakalin (Ellis et al. 2015) uncritically used oil-bodies characteristics and reported N. lescurii for Magadan Province in North East Asia. To analyze the differences and various (geographical, morphological, ecological) relationships between $N$. japonica and $N$. lescurii were the main goal of the present account.

\section{MATERIAL AND METHODS}

For the comparison we studied type specimen of Nardia japonica in G (G11787/64213) and material available to us from Russia both named as N. japonica and N. lescurii. In total 44 specimens that come mostly from the Russian Far East were studied. Three additional specimens of Nardia japonica were examined from Japan that also cited in the list of specimens examined. Many specimens were examined shortly after collecting for oil bodies observation. The obtained data were compared with treatment of N. lescurii in Schuster (1969) as well as with available material of the latter species from the Eastern North America.

\section{RESULTS AND DISCUSSION}

Indeed, it was convincingly showed by Furuki (1997) two different species were before fallen into the single portmanteau under the name Nardia japonica in Japan. Two species are quantitatively different in size and coloration and strongly qualitatively differs in oil body characters and eco- 
logy. One of those taxa was named by Furuki as N. japonica and the second one was referred to Appalachian N. lescurii. The first of all we cannot accept the proposition that the plants he named as $N$. lescurii is the same with true $N$. lescurii from Eastern North America. At the second our study of holotype and isotype of $N$. japonica showed that it does not agree with plants named as N. japonica by Furuki. Afterwards we found that $N$. lescurii in the description provided by Furuki (1997) (and also plants reported under this name in Ellis et al. 2015) is well agreed with plants in the types of N. japonica. Therefore the plants bearing smooth-surfaced, homogenous oil-bodies belong to another taxon. Despite special search we did not find any described taxa that would unite homogenous oil bodies, deeply divided leaves and large regular underleaves. We propose the mentioned plants belongs to a new, previously undescribed species that is described below as $N$. pacifica. We prefer to give the species epithet "pacifica" basing on relative frequency of that species in the areas adjacent to North-Western Pacific, although the plants mentioned by Schljakov (1981) from European North may also belong to the same taxon, but not to N. japonica s. str.
Likely the treatment of Nardiajaponica in "Jungermanniaceae of Japan" (Amakawa 1959) may be based on two different species and includes both traits of $N$. pacifica and true $N$. japonica s. str. When we started to study oil bodies characteristic, we found that the majority of specimens before called as $N$. japonica supposedly should be renamed to N. lescurii, if to accept Furuki's (1997) point of view. However, the study of type has revealed that Furuki's concept of $N$. japonica is the continuation of incorrect understanding of the species introduced by Amakawa (1959) who first ascribed homogenous oil bodies to $N$. japonica basing on the specimen most probably belonging to $N$. pacifica and that was collected by Y. Kuwahara in Daisetsu Mt. (Hokkaido).

The comparison of three (also $N$. lescurii) aforementioned taxa is placed in Table 1, where the most information on 'true' N. lescurii is derived from Schuster (1969). The data on $N$. japonica are mostly from the type specimens. In addition, since type material is certainly somewhat limited, we tested all available morphological parameters that would enrich the information on the taxon variability based on other specimens examined. In the most cases mentioned parameters fully coincided with the type, but in some well

Table 1. The comparison Nardia pacifica with morphologically related species

\begin{tabular}{|c|c|c|c|}
\hline Feature & N. japonica & $N \cdot$ pacifica & N. lescurii \\
\hline $\begin{array}{l}\text { The width of normally } \\
\text { developed shoots }\end{array}$ & $0.4-0.55\{-1.0\} \mathrm{mm}$ & $1.0-1.4 \mathrm{~mm}$ & $0.8-1.8 \mathrm{~mm}$ \\
\hline Rhizoids & a few to numerous & a few to absent & rather numerous \\
\hline Leaf insertion & subtransverse, rarely oblique & oblique, rarely subtransverse & oblique \\
\hline $\begin{array}{l}\text { Leaf size, length } \times \text { width, } \\
\mu \mathrm{m}\end{array}$ & $\begin{array}{l}200-300\{-600\} \times 300-400\{- \\
700\}\end{array}$ & $500-800 \times 500-1000$ & $350-650(-900) \times 400-1000$ \\
\hline Leaf lobes & subequal & mostly unequal, rarely subequal & subequal \\
\hline Leaf sinus depth & $1 / 5-1 / 4$ & $1 / 5-1 / 3$ & $1 / 10-1 / 4$ \\
\hline Leaf margin & loosely to distinctly crenulate & entire & entire \\
\hline $\begin{array}{l}\text { Midleaf cells } / \text { cells along } \\
\text { leaf margin, length } \times \text { width, } \\
\mu \mathrm{m}\end{array}$ & $24-32 \times 24-32 / 21-24$ & $22-40 \times(17-) 22-32 / 15-25$ & $25-56 \times 23-44 / 20-24(30)$ \\
\hline Oil bodies in midleaf cells & $\begin{array}{l}\{2-3 \text { per cell, coarsely } \\
\text { granulate*, } 9-20 \times 6-13 \mu \mathrm{m}\}\end{array}$ & $\begin{array}{l}2-3 \text { per cell, smooth to loosely } \\
\text { segmented into } 2-3 \text { segments, } \\
\text { homogenous, } 6-13 \times 5-10\end{array}$ & $\begin{array}{l}(2-) 3-5(-6) \text { per cell, } 10- \\
20 \times 7-10 \mu \mathrm{m} \text {, finely granulate- } \\
\text { papillose }\end{array}$ \\
\hline General habit & $\begin{array}{l}\text { fine soil in the areas of } \\
\text { disturbed vegetation cover, } \\
\text { in patches incrusted by soil; } \\
\text { from North Hemiarctic to } \\
\text { hemiboreal communities }\end{array}$ & $\begin{array}{l}\text { inside of moss patches in } \\
\text { closed moss synusia, in pure } \\
\text { patches or interwoven with } \\
\text { other liverworts }\end{array}$ & $\begin{array}{l}\text { damp soil and rocks, also } \\
\text { boggy sites in mountain slopes; } \\
\text { hemiboreal to cool temperate, } \\
\text { also probably boreal (as } \\
\text { exception) }\end{array}$ \\
\hline Typical associates & $\begin{array}{l}\text { Nardia assamica (Mitt.) } \\
\text { Amakawa, Endogemma caespiticia } \\
\text { (Lindenb.) Konstant., Vilnet \& } \\
\text { A.V. Troitsky }\end{array}$ & $\begin{array}{l}\text { Lophozia ventricosa (Dicks) } \\
\text { Dumort., Scapania subalpina } \\
\text { (Nees ex Lindenb.) Dumort. }\end{array}$ & $\begin{array}{l}\text { Diplopbyllum apiculatum (A. } \\
\text { Evans) Steph., Calypogeia } \\
\text { sullivantii Austin, Pellia epiphylla } \\
\text { (L.) Corda, Pallavicinia lyellii } \\
\text { (Hook.) Gr }\end{array}$ \\
\hline Ecological preference & mesophyte & hygrophyte & meso-hygrophyte \\
\hline
\end{tabular}

* Although Furuki (1997) indicated grape-cluster oil body type, his figure and our observations suggest coarsely granulate oil bodies that are different from typical grape cluster type as in, e.g., Calypogeia integristipula Steph. 
developed and robust phases the plants might be somewhat larger. In those cases we put this 'extra'-diapason in figure brackets in the description of $N$. japonica in the Table 1.

The basic differences between Nardia pacifica and N. japonica lie in two aspects: morphology (including oil bodies characteristics) and ecological preferences. Oil bodies of $N$. japonica are coarsely granulate, whereas that of $N$. pacifica are virtually smooth or shallowly 2-3-segmented. Plants of $N$. japonica characterized by narrower shoots and smaller, not so deeply incised leaves with obtuse leaf lobes in the comparison with N. pacifica (Table 1). The stems of N. japonica are merely stout and within its mat (that is mostly loose) there are a lot of erect shoots that are not deformed in the drying. On the contrary, $N$. pacifica may produce erect shoots only in dense patches and always becomes crooked in dry condition.

In respect of habitat, $N$. japonica prefers bare substrata in free of closed vegetation places, like fine soil along stream, stones near streams covered with thin soil and also various man-made habitats (path- and road-sides, waste lands, etc.), the plants of $N$. japonica are commonly characteristically incrusted by soil particles. Unlike to the latter, N. pacifica prefers well formed bryophyte synusia and seems to be less desiccation tolerant than $N$. japonica that easily surviving in long drying. This difference in ecology reflects also in distribution pattern of the both species. Although both taxa has largely sympatric areas, the area of $N$. pacifica is narrower and limited by sites under strong influence of wet air masses from ocean as well as also daily and very local moisturizing factors like valley's fogs, etc. Whereas N. japonica spreading much farther inland of continent and known as far as in Kolyma Upland and probably (the specimen was not checked) in eastern Yakutia. The holotype of N. japonica represents relatively large (especially for Stephani's types) specimen with small plants incrusted by fine soil that belong to two taxa: N. japonica and N. assamica.

Nardia lescurii is estimated as the third taxon of this group of morphologically related taxa. However, it differs from the both in oil body characteristics and distribution. Moreover, $N$. lescurii may be confused with $N$. insecta (due to shortly and narrowly incised leaves, cf. Schuster 1969) rather than with either $N$. japonica or $N$. pacifica. Well developed N. lescurii is never as small as true $N$. japonica and has never so deeply and widely incised leaves as in N. pacifica.

\section{Nardia pacifica Bakalin sp. nov.}

Description (Fig. 1, 2). Plants in loose to merely dense patches, erect to ascending (rarely creeping in depauperate phases), pale greenish, rarely green, sometimes with brown or rusty tint near shoot apices or purplish to almost purplegreen in leaf lobes in apical part of shoot, commonly soft and gentle, but under impact of running water become more rigid, small plants from $0.7 \mathrm{~mm}$ wide, well developed plants 1-1.4 mm wide and 7-15 mm long, slightly pellucid. Stem more or less straight to slightly flexuous, sparsely laterally branched, pale greenish to whitish, 200-400 $\mu \mathrm{m}$ wide; cross section slightly transversely elliptic, without differentiation into strata, in inner part cells slightly larger than in outer layer, $17-28 \mu \mathrm{m}$ in diameter, thin-walled, trigones small, concave, cells along margin $12-18 \mu \mathrm{m}$ in diameter, thin-walled, with small to moderate in size, concave trigones. Rhizoids sparse (virtually absent in smaller plants), originated from ventral side of stem in the areas adjacent to underleaf bases, obliquely spreading in unclear fascicles or loosely separated. Leaves obliquely to subtransversely inserted, obliquely to almost erect spreading, obliquely oriented, plane or very slightly concave, commonly with slightly recurved sinus, not or barely decurrent dorsally and ventrally, although insertion line sometimes suddenly curved down in both sides, sometimes loosely connate with underleaf in one side of the latter, 500-800×500-1000 $\mu \mathrm{m}$, trapezoidal to obliquely trapezoidal or widely ovate to transversely elliptic, widest below middle or in lower third, divided by almost crescentic or $\mathrm{U}$ - to $\mathrm{V}$-shaped sinus with obscurely or evidently recurved base, sinus descends to $1 / 5-1 / 3$ of leaf length and divide the leaf into two unequal or subequal triangular, mostly acute lobes that commonly turned inward, leaves unistratose to base or bistratose very near to leaf base ( $2-3$ cells high from the base). Underleaves obliquely spreading, arcuately inserted, with apex turned to the stem or nearly straight, $300-400 \times 100-200 \mu \mathrm{m}$, widely triangular to spatulate-triangular, loosely crispate at margin or with 1-2 obtuse and short teeth in one or both sides near middle, commonly ending (as well as in underleaf apex) with slime papilla. Midleaf cells thin-walled, subisodiametric or shortly oblong, $22-40 \times(17-) 22-32 \mu \mathrm{m}$, trigones small to moderate in size, convex, cuticle smooth; cells along margin 15-25 $\mu \mathrm{m}$, nearly thin-walled, trigones moderate. [Otherwise unknown].

Holotypus: RUSSIA. KamchatKa Territory. East Kamchatka, upper course of Nalycheva River, near Pinachevsky Pass $\left(53^{\circ} 26^{\prime} 31^{\prime \prime N} 158^{\circ} 39^{\prime} 08^{\prime \prime E}\right), 900 \mathrm{~m}$ alt., alpine belt, moist boulder near stream. Leg. Vadim A. Bakalin, K-67-7-15, 19 August 2015 (VBGI).

Other specimens examined: RUSSIA. KAMCHAtKa Territory, Kamchatsky Peninsula (56 07'26"N 16250'24"E), $920 \mathrm{~m}$ alt., V. Bakalin, K-3-7-06 (VBGI), Nalychevo Valley (5326'31"N 158 39'08"E), 900 m alt., V. Bakalin, K-67-3-15 (VBGI); Magadan Province, Magadanka

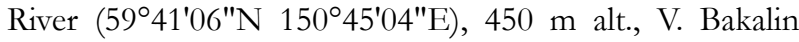
Mag-46-29-11 (VBGI); Republic of Karelia, Kojtajoki River, A. Maksimov, s.n. (VBGI); Sakhalin Province, Itu-

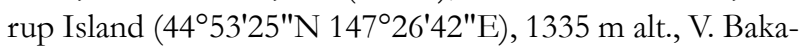
lin, K-15-30-15 (VBGI), (45²9'27"N 148 49'06"E), $530 \mathrm{~m}$ alt., V. Bakalin, K-76-24-15 (VBGI). U.S.A. WASHINGTON, Table Mount $\left(48^{\circ} 30^{\prime} \mathrm{N} 120^{\circ} 45^{\prime} \mathrm{W}\right)$, N. Konstantinova, A92/5-95 (KPABG, duplicate in VBGI).

Distribution: Due to data based on study of living material the species is quite sparse in the areas under strong influence of Pacific wet air masses, occurring from $56^{\circ} \mathrm{N}$ to ca. $40^{\circ} \mathrm{N}$ in Asia. The distribution outside of this area is unclear. The reports of N. japonica from North America (Hong \& Váña 2000) are probably based partly on $N$. pacifica and partly on true N. japonica. Morphologically the specimen cited above for Washington (specimens examined section), suspects $N$. pacifica. The same may be expected from indication of homogenous oil bodies in Hong \& Váňa 


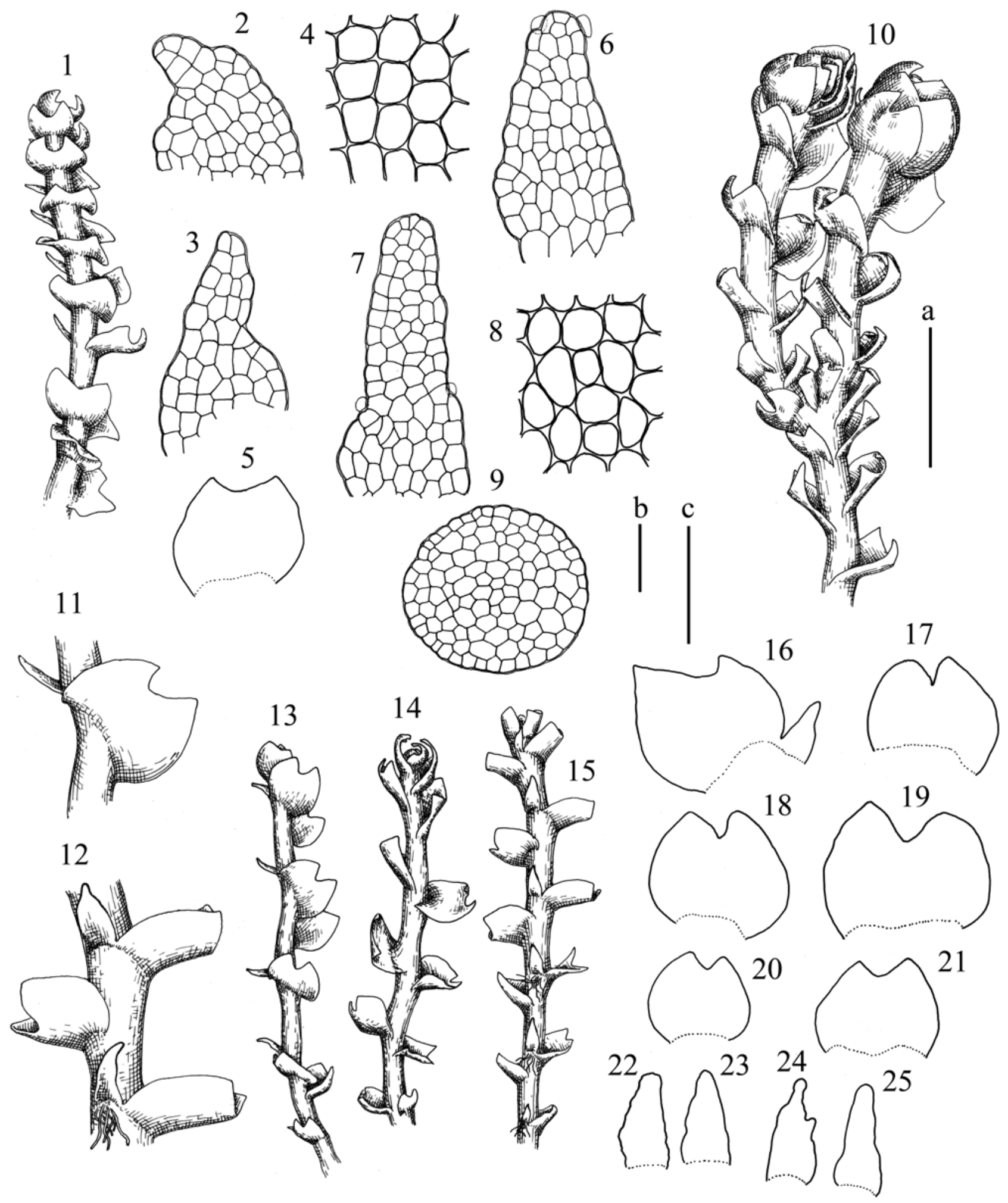

Figure 1 Nardia pacifica Bakalin: 1, 10, 13-15 - plant habit; 2, 3, 6, 7, 22-25 - underleaves; 4, 8- midleaf cells; 5, 16-21 - leaves, 9 - stem cross section; 11, 12 - shoot fragment (1-5 - from K-76-24-15; 6-9, 11-25 - from K-67-7-15; 10 - from K-67-11-15, all in VBGI). Scales: a - 1 mm, for $1,10,13-15 ; \mathrm{a}-500 \mu \mathrm{m}$, for 11,12 ; b - $50 \mu \mathrm{m}$, for 4,5 ; b $-100 \mu \mathrm{m}$, for $2,3,6,7,9$; c $-500 \mu \mathrm{m}$, for $5,16-25$

(2000), although it is not evident whether authors observed this feature in American plants or took this information from Amakawa (1959) or elsewhere. The similar situation is with the specimen from the Republic of Karelia (the area under Atlantic influence). Morphologically it is quite similar to true N. pacifica. The record from the Republic of Komi in North East Russia may belong to N. pacifica, if Schljakov (1981) provided in his book data on oil bodies basing on the material from the latter republic.

To fix morphological concept of $N$. japonica, below we provide the morphological description based entirely on the plants in holotype of the taxon (G11787/64213). 

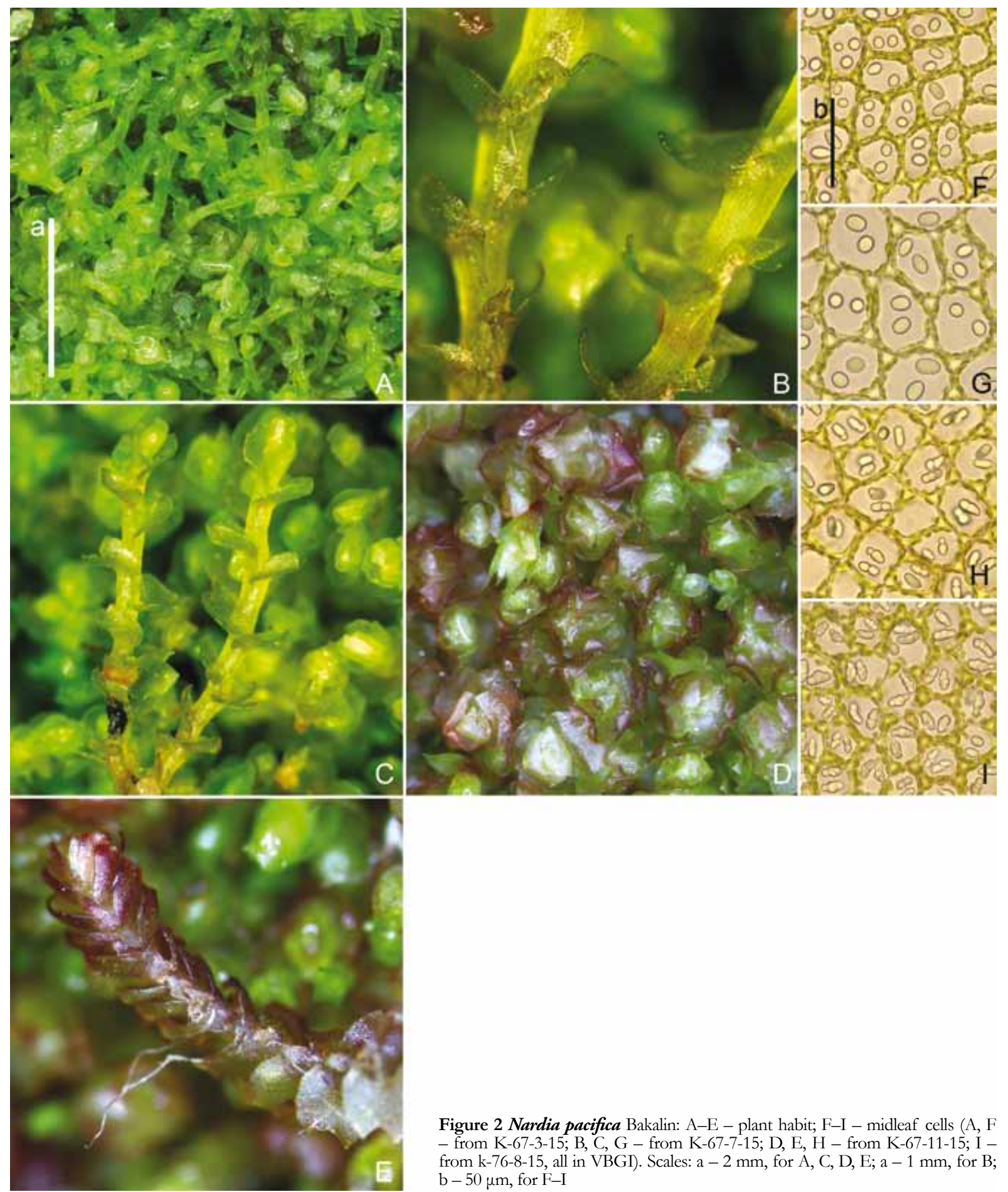

Figure 2 Nardia pacifica Bakalin: A-E - plant habit; F-I - midleaf cells (A, F - from K-67-3-15; B, C, G - from K-67-7-15; D, E, H - from K-67-11-15; I from k-76-8-15, all in VBGI). Scales: a $-2 \mathrm{~mm}$, for A, C, D, E; a $-1 \mathrm{~mm}$, for B; $\mathrm{b}-50 \mu \mathrm{m}$, for $\mathrm{F}-\mathrm{I}$

Nardia japonica Steph. Bull. Herb. Boissier 5: 101. 1897.

Description (Fig. 3, 4). Plants small, rigid, incrusted with soil, growing with admixture of Nardia assamica, brownish, with purple tint, $400-550 \mu \mathrm{m}$ wide and 3-5 mm long, forming loose patches. Rhizoids common, colorless, in obliquely spreading unclear fascicles, originated near from ventral side of stem mostly near underleaf base, but not only there. Leaves contiguous to distant (subimbricate near apex of female branches), subtransversely to obliquely inserted, obliquely spreading, subtransversely oriented, concave to almost plane, trapezoidal to widely ovate when flattened in the slide, $200-300 \times 300-400 \mu \mathrm{m}$, divided by Uto $\mathrm{V}$-shaped sinus, descending to $1 / 5-1 / 4$ of leaf length into two triangular, more or less acute lobes. Underleaves spatulate, in the most cases connate with one of leaf of the corresponding leaf pair. Midleaf cells 24-32×24-32 $\mu \mathrm{m}$, subisodiametric, thin-walled, trigones moderate in size, convex, cuticle smooth; cells along leaf margin 21-24 $\mu \mathrm{m}$, 


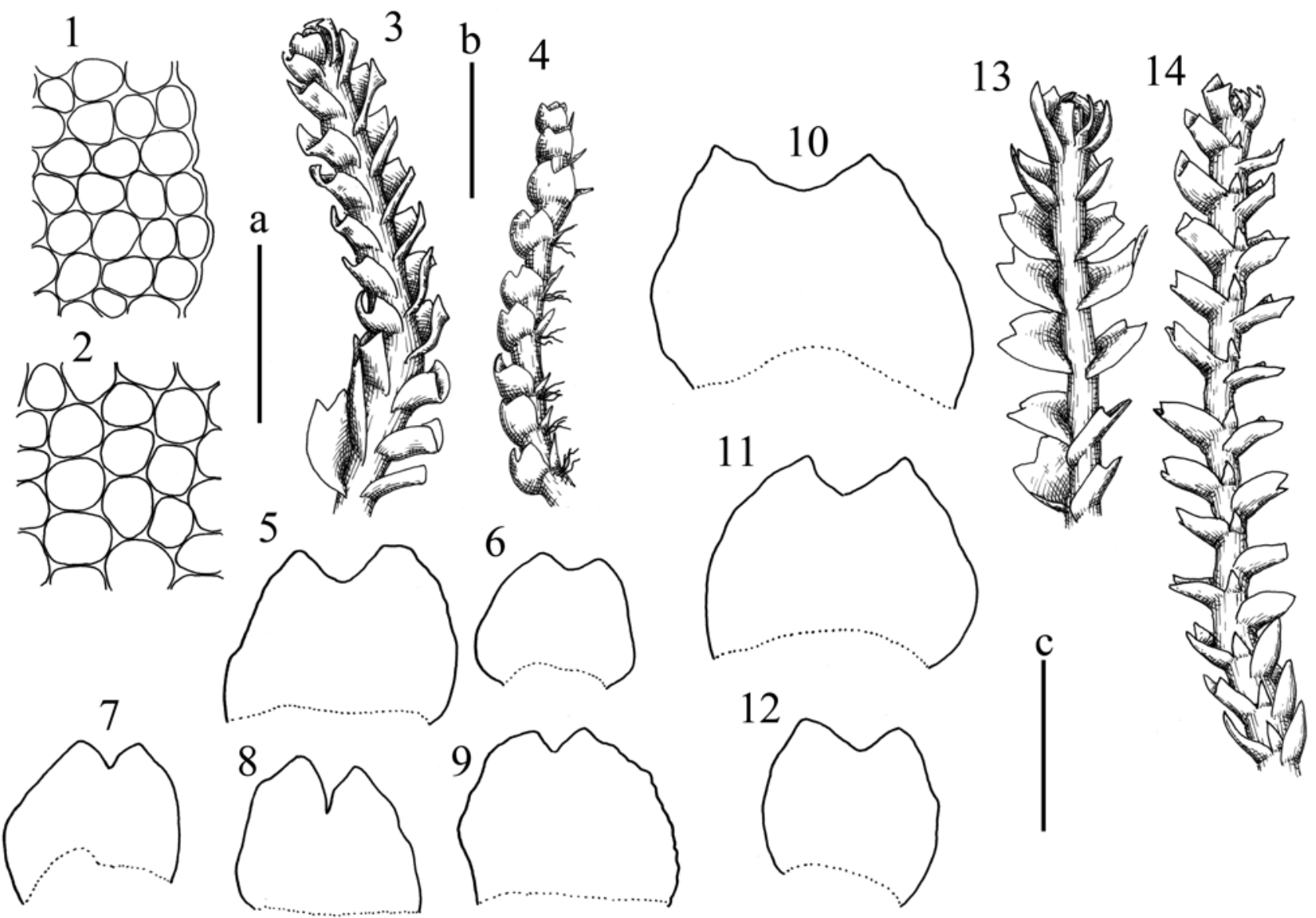

Figure 3 Nardia japonica Steph.: 1 - cells along leaf margin; 2 - midleaf cells; 3, 4, 13, 14 - plant habit; 5-12 - leaves (1-9 - from holotype, G00064213/11787; 10-14 - from K-61-8-15,VBGI). Scales: a - $100 \mu \mathrm{m}$, for 1, 2; b-500 $\mu \mathrm{m}$, for 3, 4, 13, 14; c - 300 $\mu \mathrm{m}$, for 5-12

nearly thin-walled, with thickened external wall, trigones moderate to large in size, slightly convex to slightly concave. Dioicous. Androecia intercalary, with 4-6 pairs of bracts, nearly spicate. Perianth terminal, without subfloral innovations, short conical, hidden within bracts, perigynium ca. 2-4 perianth lengths, with 2-3 pairs of bracts, forming angle $60-80^{\circ}$ with stem axis, rhizogenous; bracts similar to leaves, but wider and not so deeply bilobed (commonly only shortly retuse), bracteole spatulate, connate with one bract of corresponding pair or free. Capsule wall bistratose, outer cells subquadrate to rectangular $29-48 \times 24-29 \mu \mathrm{m}$, with 3-5 nodulose thickenings in each vertical wall; inner layer cells oblong, sometimes loosely flexuous, 40-72×6.5$13 \mu \mathrm{m}$, with 5-10 semicircular bands. Spores 10-12 $\mu \mathrm{m}$ in diameter, brown, papillose. Elaters bispiral, 80-104×8-10 $\mu \mathrm{m}$.

Distribution: The species is presumably distributed around north Pacific northward from ca $40^{\circ} \mathrm{N}$ in Asia (stretching westward to the Republic of Yakutiya) and to the similar latitude in North America, as well as in some areas in North Europe under Atlantic air masses influence. Oil bodies study has confirmed it for Japan (Furuki 1997, under N. lescurii), Kurils and Kamchatka in Asia as well as Murmansk Province (see specimens examined) in North Europe. The species possesses larger range than do N. pacifica. It is fairly common as northward as in Kolyma Plateau.
In the sites of discontinuous vegetation cover it is the most common species of the genus in Kamchatka (many specimens on which the record of this taxon based for Kamchatka and adjacent lands in Bakalin, 2009, were identified basing on dry material and are not cited below).

Specimens examined of Nardia japonica: RUSSIA. Kamchatka Territory, Ganal'sky Range (5356'27"N $\left.158^{\circ} 01^{\prime} 31^{\prime \prime E}\right), 900 \mathrm{~m}$ alt., V. Bakalin, K-43-2-15 (VBGI), $\left(53^{\circ} 56^{\prime} 45^{\prime \prime} \mathrm{N} 158^{\circ} 01^{\prime} 56^{\prime \prime E}\right), 900 \mathrm{~m}$ alt., V. Bakalin, K-44-23-15 (VBGI), Karaginsky Island (58 $57^{\circ} 15^{\prime \prime N}$ $\left.164^{\circ} 15^{\prime} 05^{\prime \prime E}\right), 490 \mathrm{~m}$ alt., V. Bakalin, K-22-2-05 (VBGI), (58 $\left.57^{\prime} 16^{\prime \prime} \mathrm{N} 164^{\circ} 14^{\prime} 43^{\prime \prime E}\right), 380 \mathrm{~m}$ alt., V. Bakalin, K-266-05 (VBGI), (58 57'58"N 164¹3'34"E), $200 \mathrm{~m}$ alt., V. Bakalin, K-23a-9-05 (VBGI), (58 58'32"N 164¹1'35"E), $120 \mathrm{~m}$ alt., V. Bakalin, K-29-36-05 (VBGI), Nalychevo Valley (5334'59"N 15854'41"E), $800 \mathrm{~m}$ alt., V. Bakalin, K-61-8-15 (VBGI); Khabarovsk Territory, Gobilli River (49¹6'00"N 138 21'35"E), 420 m alt., V. Bakalin, Kh71-13-09 (VBGI), Lanzhinsky Mountains (59²5'25"N $\left.143^{\circ} 25^{\prime} 05^{\prime \prime E}\right), 400 \mathrm{~m}$ alt., V. Bakalin, Kh-25-13-08 (VBGI), $\left(59^{\circ} 26^{\prime} 32^{\prime \prime N} 143^{\circ} 30^{\prime} 44^{\prime \prime E}\right), 110 \mathrm{~m}$ alt., V. Bakalin Kh21-3-08 (VBGI), (59 $\left.26^{\prime} 39^{\prime \prime N} 143^{\circ} 28^{\prime} 13^{\prime \prime E}\right), 210 \mathrm{~m}$ alt., V. Bakalin, Kh-33-7-08 (VBGI); Magadan Province, Magadanka River (59 41'06"N 15045'04"E), $450 \mathrm{~m}$ alt., V. Bakalin, Mag-46-34-11 (VBGI), Marchekansakaya Sopka Mt. (59³1'19"N 15049'23"E), 350 m alt., V. Bakalin, Mag- 

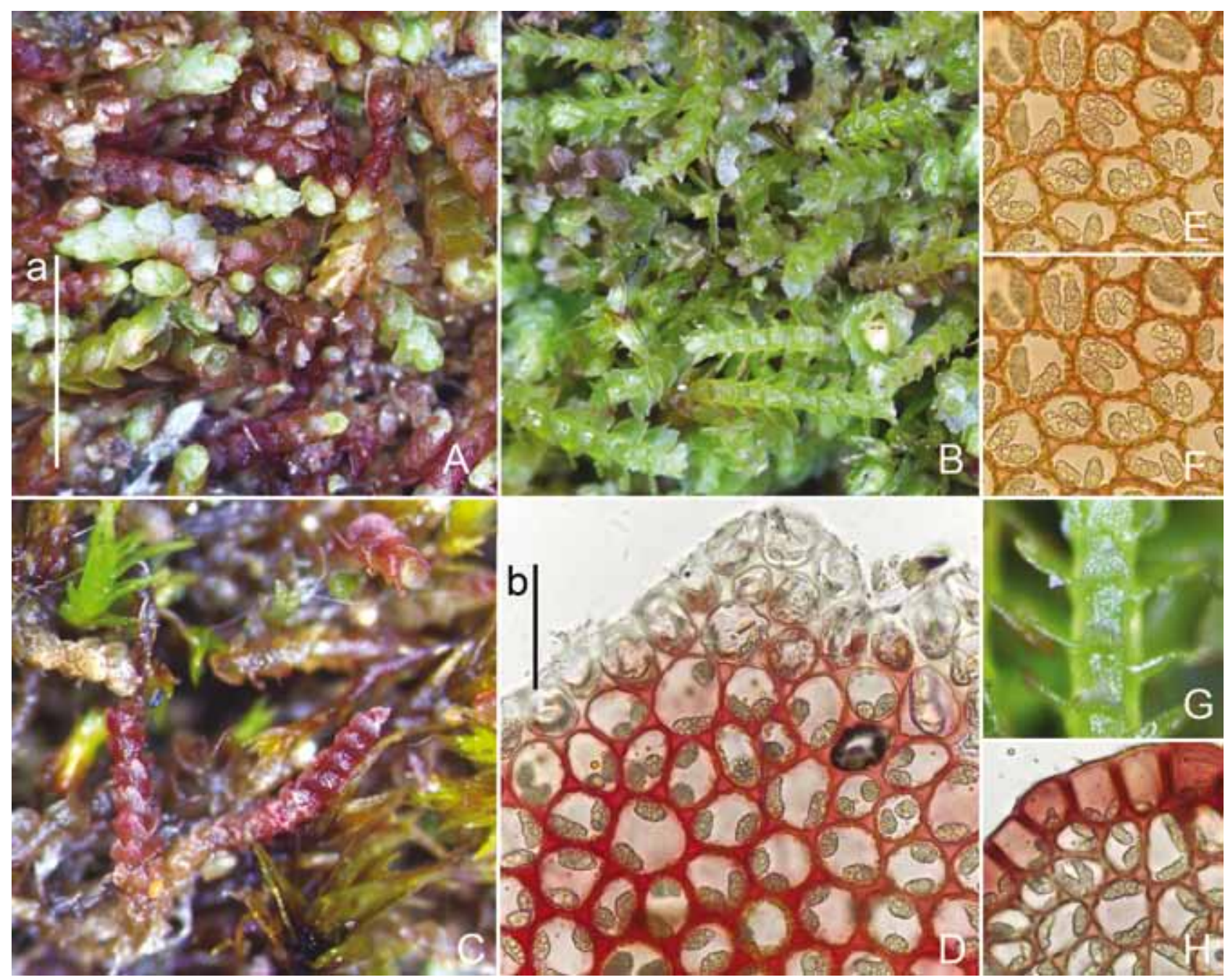

Figure 4 Nardia japonica Steph.: A-C - plant habit; D, H - leaf margin; I, F - midleaf cells; G - shoot ventral view, fragment (A, E - from K-4423-15; B, F, G - from K-61-4-15; C, D - from Mur-32-3-15; H - from Mag-21-27-14, all in VBGI). Scales: a - 1 mm, for A-C; a - $400 \mu \mathrm{m}$, for G; $\mathrm{b}-50 \mu \mathrm{m}$, for $\mathrm{D}, \mathrm{E}, \mathrm{F}, \mathrm{H}$

61-5-11 (VBGI), Oksa River (59³9'20"N 150²7'20"E), $10 \mathrm{~m}$ alt., V. Bakalin, Mag-25-22-11 (VBGI), Annachag Range $\left(62^{\circ} 06^{\prime} 46^{\prime \prime} \mathrm{N} 149^{\circ} 28^{\prime} 58^{\prime \prime} \mathrm{E}\right), 1090 \mathrm{~m}$ alt., V. Baka-

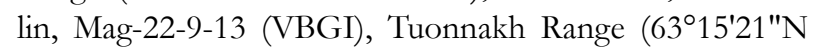
15132'33"E), 780 m alt., V. Bakalin, Mag-42-11-11 (VBGI),

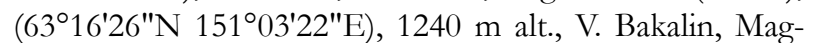
38-10-11 (VBGI), (631'22"N 15125'04"E), $660 \mathrm{~m}$ alt., V. Bakalin, Mag-40-8-11 (VBGI); Murmansk Province, Khibiny Mts. (67³9'00"N 3338'35"E), $560 \mathrm{~m}$ alt., V. Bakalin, Mur-32-3-15 (VBGI); SAKHALin Province, Iturup Island (4511'28"N 148 20'41"E), 20 m alt., V. Bakalin, K-80-1715 (VBGI), (45²9'27"N 14849'06"E), 530 m alt., V. Bakalin, K-76-9-15 (VBGI), Kunashir Island, V. Bakalin, K-442-06 (VBGI), (44²7'22"N 14607'19"E), $1100 \mathrm{~m}$ alt., V. Bakalin, K-38-7-06 (VBGI), Nabil'sky Range (5044'45"N

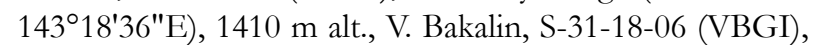
$\left(50^{\circ} 44^{\prime} 50^{\prime \prime N} 143^{\circ} 17^{\prime} 17^{\prime \prime E}\right), 950 \mathrm{~m}$ alt., V. Bakalin, S-3011-06 (VBGI), Nikolayevka (5340'26"N 142³6'58"E), $35 \mathrm{~m}$ alt., V. Bakalin, S-36-8-09 (VBGI), Pilenga River (5101'31"N 14250'50"E), $160 \mathrm{~m}$ alt., V. Bakalin, S-29-7-

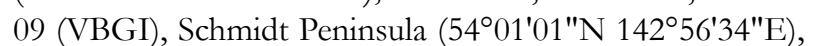
$50 \mathrm{~m}$ alt., V. Bakalin, S-41-16-09 (VBGI), Shikotan Island
(434' $\left.52^{\prime \prime} \mathrm{N} 146^{\circ} 41^{\prime} 03^{\prime \prime E}\right), 160 \mathrm{~m}$ alt., V. Bakalin, K-442-07 (VBGI). JAPAN. Hokkaido Prefecture, Oakandake Mt., 1300 m alt., Takita K., 2440 (SAPT), Nagayama Mt., $1400 \mathrm{~m}$ alt. Takita K., 2469 (SAPT), Shiretoko, Faurie U., 10930, 25.VIII.1893 (KYO).

\section{ACKNOWLEDGEMENTS}

VB is sincerely grateful to Dr. Michelle Price $(G)$ for her kind help during his visit to Geneva. The line drawings were kindly compiled by Mr. M.A. Bakalin, to whom authors are sincerely grateful. The work was partially supported by the Russian Foundation for Basic Researches (15-34-20101).

\section{LITERATURE CITED}

Amakawa, T. 1959. Family Jungermanniaceae of Japan. I. The Journal of the Hattori Botanical Laboratory 21:248-291.

Bakalin, V.A. 2009. Flora and phytogeography of liverworts Marchantiophyta, Anthocerotophyta) of Kamchatka Peninsula and Adjacent Islands. Tovarishchestvo nauchnyh izdanii KMK, Moscow, 367 pp. (in Russian). [Бакалин В.А. 2009. ФАора и фитогеография печеночников (Marchantiophyta, Anthocerotophyta) Камчатки и примегающих остро- 
вов. Москва: Товарищество научных изданий КМК. 375 c.].

Ellis, L.T., A.K. Asthana, A. Srivastava, V.A. Bakalin, H. Bednarek-Ochyra, M.J. Cano, J.A. Jiménez, M. Alonso, J. Deme, J. Csiky, V.R. Smith, A. Stebel, S. Ştefănut, M. Subkaite, B.Y. Sun, A. Uselienė, G. Uyar, J. Váňa, Y.J. Yoon \& S.J. Park 2015. New national and regional bryophyte records, 43. Journal of Bryology 37(2):128-146.

Furuki, F. 1997. Nardia lescurii (Aust.) Underw. (Jungermanniaceae, Hepaticae) new to Japan, hitherto known only from the Appalachian Mountains. Bryological Research 7(3): 69-71 (in Japanese).

Hong, W.S. \& J. Váňa 2000. The distribution of Nardia in western North America. Lindbergia 25:9-14.

Potemkin, A.D. 2004. Hepatics from the North Karelia Biosphere Reserve and adjacent territories: rare and new species for Finland and Karelia borealis. Memoranda Societatis pro Fauna et Flora Fennica 80:69-73.
Schljakov, R.N. 1981. Hepatics of the North USSR. Vol. 4. Liverworts: Jungermanniaceae - Scapaniaceae. Nauka, Leningrad. 221 pp. (in Russian). ШАяков Р.Н. 1981. Печеночные мхи Севера СССР, вып. 4. Печеночники: Юнгерманниевые - Скапаниевые. $\Lambda .:$ Наука. 221 с.].

Schuster, R.M. 1969. The Hepaticae and Anthocerotae of North America. Vol. 2. Columbia University Press, New York. 1062 pp.

Stephani, F. 1897. Hepaticae Japonicae. Bulletin Herbier Boissier 5:76-108.

Váňa, J. 1976. Studien über die Jungermannioideae (Hepaticae) 10. Nardia. Folia Geobotanica et Phytotaxonomica 11: 367-425.

Yamada, K. \& Z. Iwatsuki 2006. Catalog of the hepatics of Japan. The Journal of the Hattori Botanical Laboratory 99: $1-106$. 